\title{
O CZTERECH WĄTPLIWOŚCIACH DOTYCZĄCYCH KSIĄŻKI ALEKSANDRY KORCZAK ZGODA NA SIEBIE. PRZEEAMYWANIE IMPERATYWU SOCJALIZACJI W CYKLU O MUMINKACH AUTORSTWA TOVE JANSSON
}

\author{
Michaє BOMASTYK ${ }^{3}$ \\ (Uniwersytet Mikołaja Kopernika w Toruniu)
}

Korczak, Aleksandra Maria. Zgoda na siebie. Przełamywanie imperatywu socjalizacji w cyklu o Muminkach autorstwa Tove Jansson. Warszawa: Wydawnictwo Stowarzyszenia Bibliotekarzy Polskich, 2016. 112 S.

Badania ksenologiczne, heterologiczne oraz te związane $\mathrm{z}$ teoriami wykluczeń są bardzo zróżnicowane oraz interdyscyplinarne - zagadnieniami tymi zajmują się przedstawiciele wielu dziedzin naukowych: filozofowie, socjologowie, kulturoznawcy, literaturoznawcy etc. Zagadnienia obcości oraz inności są ciekawe, ponieważ badacze patrzą na nie $\mathrm{z}$ różnych perspektyw, które można ze sobą porównać. Jedną z badaczek krytycznie analizujących obcość jest literaturoznawczyni, Aleksandra Korczak, naukowczyni zajmująca się literaturą popularną, dziecięcą i młodzieżową. Korczak jest autorką książki Zgoda na siebie, w której opisuje utopijny świat Muminków, stworzony przez fińską artystkę Tove Jansson. Korczak przybliża czytelnikom historię literackich bohaterów, by postawić tezę, że warunkiem tego, aby człowiek mógł żyć

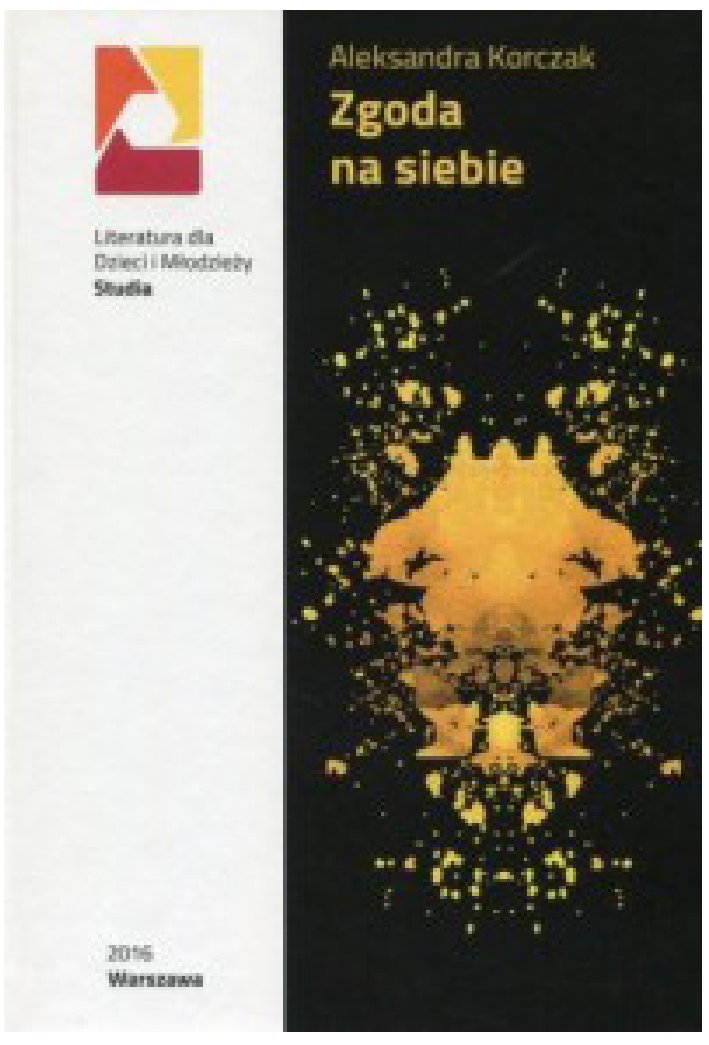

3 E-mail: michalbomastyk@gmail.com 
w zgodzie z samym sobą, jest nie tylko wyrażanie tytułowej zgody na siebie, lecz także afirmowanie innych osób oraz całego świata.

Książka pomimo charakteru naukowego napisana jest przystępnym językiem, dzięki czemu jej adresatami mogą być czytelnicy niezwiązani ze środowiskiem akademickim. Autorka co prawda prezentuje w omawianej książce teorie naukowe, co jest godne podkreślenia, jednakże czyni to w sposób, który mógłby zaciekawić czytelnika o różnorakich zainteresowaniach, niekoniecznie filozoficznych czy socjologicznych. Czytając książkę Korczak, możemy pokusić się o sformułowanie wniosku, że jest to nowy podręcznik na temat sposobu wychowania dzieci i młodzieży, ponieważ autorka $\mathrm{w}$ pierwszym rozdziale Zgody na siebie prezentuje teorie pedagogiczne funkcjonujące od XIX wieku, a także zestawia je i porównuje z tzw. teoriami antypedagogicznymi, których przedstawiciele, np. Janusz Korczak ${ }^{4}$, zwracali uwagę, że ówczesny sposób wychowywania dzieci i młodzieży był niewystarczający, ponieważ ograniczał wolność podopiecznych i nie pozwalał im samodzielnie myśleć (Korczak 19-35). Wydaje się, że Aleksandra Korczak jest tego samego zdania, gdyż wielokrotnie zwraca w swej książce uwagę na takie metody wychowawcze, które nie są zgodne z tradycyjnym modelem ${ }^{5}$, i przekonuje o ich słuszności, np. wskazuje na sposób, w jaki Mama Muminka rozmawia ze swym synem, oraz na to, że pozwala mu samodzielnie podejmować decyzje, w tym także te, które mogą negatywnie wpłynąć na jego egzystencję. Dzięki temu podopieczny może uczyć się na swoich błędach oraz wykorzystać życiowe porażki do tego, by uczynić życie lepszym. Dlatego też książka Korczak powinna zostać przeczytana nie tylko przez pedagogów, lecz także przez rodziców oraz dzieci, aby mogli, jeśli zachodzi taka potrzeba, wspólnie wypracować nowy sposób współdziałania.

Należy również podkreślić, że analiza Doliny Muminków opisanej przez Jannson stanowi dla Korczak jedynie punkt wyjścia do tego, by zwrócić uwagę na problemy, z którymi spotykamy się w świecie współczesnym, tzn. z problemem nietolerancji oraz nieakceptacji osób nieheteronormatywnych, a także z wyobcowaniem i wykluczeniem społecznym jednostek, wynikającym z trudności dostosowania się przez nie do norm postępowania w społeczeństwie. Korczak pochyla się nad tymi ważnymi tematami, dlatego też możemy stwierdzić, że Zgoda na siebie jest nie tylko pedagogicznym podręcznikiem, lecz także zbiorem etycznych wskazówek, dzięki czemu książka ta może być wykorzystywana przez nauczycieli etyki. Chcąc jednak przeprowadzić rzetelną recenzję, pomimo sympatii, którą darzę autorkę, muszę zwrócić uwagę na pewne treści zawarte w omawianej książce, które wzbudzają wątpliwości, zwłaszcza gdy są analizowane z filozoficznej perspektywy. W mojej ocenie problematyczny jest sposób, w jaki Korczak ujmuje proces socjalizacji, normę

4 Autorka nie jest $\mathrm{z}$ nim spokrewniona.

5 To znaczy z takim, w myśl którego dzieci podległe są swoim rodzicom, zaś ich „głos jest nadal tłumiony, lekceważony, niezrozumiany" (Korczak 35). 
społeczną, inność i obcość oraz kategorię, jaką jest egoizm. Niech autorka nie ma mi tego za złe, wszak sama napisała: „Chciałabym, aby ten tekst stanowił uwerturę do refleksji wykraczającej poza omówione przeze mnie książki” (Korczak 109).

Wątpliwości budzą już określone sformułowania zawarte we wstępie książki. Autorka pisze tam o „imperatywie socjalizacji”, który uznała za dogmat, „wymóg pisania takich książek dla najmłodszych, które będą oddziaływać na nich dydaktycznie, które ukształtują odbiorcę zgodnie z wzorcami postulowanymi przez społeczeństwo" (Korczak 10). Gdybyśmy poprzestali na tej definicji, to moglibyśmy stwierdzić, że moja wątpliwość jest bezzasadna. Autorka jednakże na następnych stronach książki zdaje się poszerzać ową definicję imperatywu socjalizacji i stwierdza, że jest on społecznym wymogiem dotyczącym wszystkich jednostek żyjących w społeczeństwie, nie zaś wyłącznie jedną z wytycznych dla autorów opowiadań dla dzieci. Nie sposób nie zgodzić się z tezą, że jednostki od najmłodszych lat, przez całe swe życie przechodzą proces socjalizacji, $\mathrm{w}$ trakcie którego dowiadują się o normach postępowania funkcjonujących $\mathrm{w}$ danym społeczeństwie, następnie internalizują je w sobie - uznają za własne, dzięki czemu mogą socjalizować pozostałe jednostki. Dodajmy także, że w proces naszej socjalizacji zaangażowanych jest wiele podmiotów. Rozpoczyna się on pośród rodziny: rodziców, dziadków, rodzeństwa etc. Następnym jego etapem jest szkoła, w której rówieśnicy mają niemały wpływ na nasze postępowanie. Proces socjalizacji odbywa się także na uniwersytecie oraz w miejscu naszego zatrudnienia. Widzimy zatem, że nasze zachowanie na każdej płaszczyźnie życia poddawane jest ocenie oraz jest korygowane, jeśli nie odpowiada konkretnej normie społecznej. Postępowanie wbrew owej normie rzeczywiście możemy uznać za niewypełnianie różnorakich imperatywów, np. „,będąc mężczyzną, musisz być silny i władczy”, , ,jako kobieta nie bądź wulgarna”, "ubieraj się odpowiednio do kulturowego wizerunku płci" etc. Wydaje się jednak, że o nakazach tych możemy jedynie powiedzieć, że są one konsekwencją procesu socjalizacji, dlatego też należy postawić pytanie: czy możemy stwierdzić, że istnieje imperatyw samej socjalizacji? Podkreślmy bowiem, że imperatyw zakłada świadome działanie jednostki, w procesie socjalizacji natomiast jednostki przyjmują bezrefleksyjnie określone normy społeczne, zgodnie z którymi żyją i które stają się częścią ich tożsamości. Proces socjalizacji odbywa się mimowolnie i jednostka nie ma nad nim kontroli. Opiera się on niewątpliwie na delegowaniu nakazów i zakazów służących temu, aby jednostka nauczyła się poprawnego funkcjonowania w społeczeństwie, w mojej ocenie jednak proces ten sam w sobie imperatywem nie jest. Uważam zatem, że postawienie tezy o funkcjonowaniu w społeczeństwie imperatywu socjalizacji jest uproszczeniem i należałoby tę tezę rozwinąć, by uniknąć różnych nieporozumień.

Autorka, analizując życie Muminków, pokazuje, że funkcjonujące w społeczeństwie mechanizmy socjalizacji mają charakter opresyjny ${ }^{6}$ (Korczak 10, 19, 27). Wyka-

6 Autorka pisze, że uleganie procesom socjalizacyjnym jest poddańczym aktem (Korczak 19). 
zuje także, że jest możliwy świat, w którym jednostka będzie mogła nie ulegać imperatywom, których przyjęcie wymusza proces socjalizacji. Jako przykład Korczak podaje zbuntowaną Małą Mi, o której pisze: „Mi funkcjonuje niejako poza swoją społecznością, nie tworzy z nikim pary ani grupy, [...] nigdy nie zabiega o niczyją uwagę i przyjaźń, dzięki czemu może bez konsekwencji wyrażać arbitralne opinie i sądy" (Korczak 43). Pozostaje jednakże pytanie o to, czy w świecie, który nie jest utopijny, jednostka może funkcjonować w oderwaniu od innych osób oraz wyrażać sprzeciw wobec uczestnictwa w procesie socjalizacji. Uważam, że poza utopijnym społeczeństwem jednostka przejawiająca tego typu zachowania poniosłaby wysoką cenę za swoje czyny, mianowicie doświadczyłaby społecznego wyobcowania.

Autorka nie precyzuje także, co to znaczy, że obecnie funkcjonujące mechanizmy socjalizacji są opresyjne. Czy zatem należałoby je wszystkie zdestabilizować? Jeśli tak, to w jakim stopniu? Wydaje się, że chodzi o przeprowadzanie procesu socjalizacji dzieci w taki sposób, ażeby ich wychowanie nie ograniczało się wyłącznie do przestrzegania przez nie zakazów i wypełniania nakazów - imperatywów - dyktowanych im przez opiekunów. Zastanówmy się jednak, czy imperatyw wypowiedziany w inny sposób, tj. pozbawiony wykrzyknień, nie pozostaje wciąż nakazem? Korczak przytacza scenę, w której Paszczak kładzie na stół warzywa ze swego ogródka. Mama Muminka nie nakazuje mu wprost wziąć ze stołu owych produktów, lecz prosi go o to z uprzejmością (Korczak 63). W mojej opinii w dalszym ciągu mówimy o imperatywie i o przestrzeganiu społecznej normy, jaką jest traktowanie stołu jako miejsca, przy którym spożywa się posiłki, nie zaś jako przedmiotu, na którym kładzie się nieumyte produkty. Imperatyw ten co prawda jest osłabiony, ponieważ pozwala dziecku na wniesienie sprzeciwu oraz na podjęcie samodzielnej decyzji, mimo wszystko jednak służy temu, by dziecko zinternalizowało w sobie społeczną normę.

Uważam, że imperatywy te są potrzebne a nawet konieczne, szczególnie w życiu dziecka, które uczy się, w jaki sposób poprawnie funkcjonować w społeczeństwie. Co więcej, twierdzę, że nie ma możliwości usunięcia wspomnianych imperatywów ze społecznej przestrzeni, podobnie jak stereotypów ${ }^{7}$, ponieważ są one naszymi matrycami spojrzeń, dzięki którym kategoryzujemy świat i jest nam w nim łatwiej żyć. Ponadto, dzięki nim świat wydaje się nam bardziej racjonalnym i bezpieczniejszym miejscem, o czym pisał Walter Lippmann, twórca pojęcia stereotyp, w książce Public Opinion (Lippmann). Wydaje się zatem, że człowiek żyjący w społeczeństwie potrzebuje nakazów, norm i zasad, których musi przestrzegać, dlatego też moją wątpliwość wzbudza pełne przekonania stwierdzenie autorki, że mechanizmy socjalizacyjne są opresyjne ${ }^{8}$. Nie ulega jednak wątpliwości, że niektóre impera-

7 Nie oznacza to jednak, że nie należy podejmować prób destabilizujących funkcjonowanie stereotypów w społeczeństwie, które $\mathrm{w}$ wielu przypadkach przyczyniają się do społecznego wykluczenia jednostek.

8 Korczak twierdzi, że „idealizacja oczekiwań, przyporządkowywanie żywych osób do wyobrażeń 
tywy wynikające z procesu socjalizacji oraz stereotypy mają taki charakter. Jednym z nich, o czym słusznie wspomina Korczak, jest realizowanie heteroseksualnej normy dyscyplinującej wszystkie jednostki $w$ duchu heteronormatywnym ${ }^{9}$. Oznacza to, że od dnia naszych narodzin jesteśmy wychowywani przez naszych rodziców, potem natomiast socjalizowani przez grupy rówieśnicze, jako heteroseksualni. Norma ta z pewnością jest opresyjna dla jednostek nieheteronormatywnych, ponieważ konsekwencją niewypełniania przez nie w przestrzeni publicznej owej normy może być kara ostracyzmu społecznego. Możemy zatem jedynie stwierdzić, że wiele tych imperatywów ma charakter wykluczający, jednak nie wszystkie, chyba że przyjmiemy, iż każdy z nich ujarzmia jednostki. Wtedy także nakaz: „Kochaj swoich rodziców" byłby opresyjny, choć zgodzimy się, że jest wartościowy i potrzebny. Autorka powinna była zatem zdefiniować, czym owa opresja jest i w jaki sposób należy ją rozumieć.

Korczak stawia również tezę, że jednostka może czuć się szczęśliwa tylko wtedy, gdy wyrazi zgodę na siebie, tzn. zaakceptuje siebie, swoje wady i zalety, ułomności i talenty - swoją tożsamość. Tylko w ten sposób będzie zdolna konstruować swą podmiotowość w sposób wolny i szczęśliwy. Badaczka idzie w rozważaniach o krok dalej i zwraca uwagę, że nie wystarczy wyrażać zgody na siebie, lecz potrzeba również afirmować Innych. Jest to bardzo ważna teza z punktu widzenia filozofii. Inny, czyli każdy drugi człowiek, jest bowiem relewantną jednostką w ludzkiej egzystencji, ponieważ kształtuje doświadczenia i pozwala zmieniać postępowanie. Jak napisał francuski egzystencjalista Jean-Paul Sartre w dziele Byt i nicość, dzięki spojrzeniu Innego człowiek może odczuwać wyzwalający wstyd, ponieważ Inny uświadamia mu wulgarność jego gestów (Sartre 2007: 287-288). Bez Innego zatem człowiek nie mógłby swobodnie działać, to znaczy zmieniać kształtu otaczającego go świata, nawet gdyby w pełni wyrażał zgodę na siebie. Należy jednakże zwrócić uwagę, że autorka nie wprowadza w książce rozróżnienia na Inność oraz Obcość, wydaje się nawet, że oba te terminy traktuje jako tożsame: „Gdy w dolinie Muminków jedno stworzenie opisuje drugie, nigdy nie pojawia się $\mathrm{w}$ tym opisie ocena, która wprowadzałaby jakościujący stosunek do innych. Kategoria obcości, inności, nie bywa tutaj źródłem deprecjonowania czyichkolwiek przywar" (Korczak 61). Autorka nie stosuje terminów inność oraz obcość rozumianych w perspektywie filo-

i gotowych wzorców - oto, co niweczy usiłowanie prawdziwego, pełnego poznania drugiego człowieka" (Korczak71).

9 Zdaje się, że Autorka, choć zapewne nieświadomie, także ulega tej normie, pisząc, że "różnice, jak choćby te między płciami, są czymś naturalnym i połączenie tego, co z gruntu inne, kobiety i mężczyzny, jest zarazem e s e n cją [podkr. M.B.] tego wyjątkowego uczucia, która ma w sobie siłę stworzenia nowego życia" (Korczak 68). Zdanie to wywołuje mój sprzeciw, ponieważ słowo esencja w filozofii feministycznej kojarzy się szczególnie z determinizmem biologicznym, w myśl którego żeńskie i męskie cechy społeczno-kulturowe wynikają z uposażenia anatomicznego kobiet i mężczyzn. Użycie natomiast w zdaniu przez Korczak wyrazu esencja może wskazywać na to, że jedynie intymna relacja między mężczyzną a kobietą nosi znamiona naturalności. 
zoficznej, to zaś pozwoliłoby jej poszerzyć swą argumentację. W filozofii Inny, jak podkreśliłem powyżej, jest niezbędny w ludzkiej egzystencji. Obcego natomiast możemy opisać jako wyobcowanego Innego, którego odrzucamy, deprecjonujemy i marginalizujemy. Co więcej, Obcego możemy uczynić naszym wrogiem. Autorka podaje przykład Buki, która chciała zbliżyć się do Muminków, lecz te się jej bały i odrzucały z tego powodu. Badaczka kwalifikuje Bukę - moim zdaniem niesłusznie - używając trzech terminów: Buka jako Inna (Korczak 66), Buka jako Obca (Korczak 65), Buka jako złowroga postać (Korczak 66), podczas gdy ta zawsze przyjmuje jedną rolę i w mojej ocenie można o niej powiedzieć jedynie, że jest Obca, ponieważ Muminki ją wyobcowują oraz sytuują poza społeczeństwem. Autorka wskazuje jednakże na fragment jednego z opowiadań o Muminkach, w którym Buka staje się Inna dla Muminka (Korczak 66), tzn. przestaje być dla niego Obca. Przeżywają oni bowiem spotkanie "twarzą w twarz", podczas którego odkrywają się przed sobą i biorą za siebie nawzajem odpowiedzialność. Kategorię twarzy w filozofii wprowadza francuski filozof Emmanuel Lévinas. Spotkanie "twarzą w twarz” jest bliskie i bezpośrednie, jest ono „odpowiedzialnością, nawiedzeniem przez innego, byciem jeden-za-drugiego, narodzinami znaczenia ponad byciem" (Lévinas 152). Jedynie takie spotkanie jest realne, prawdziwe, gdyż w czasie jego trwania można poznać drugiego. Na uwagę zasługują przywołani przez Korczak Hatifnatowie, mieszkańcy utopijnego świata Muminków, którzy pozbawieni są twarzy i z tego powodu nie dają się poznać (Korczak 70). Jedynie dostrzegając twarz Innego, można poczuć z nim więź i odkryć jego tajemnice, tym samym wyrazić na niego zgodę. Muminek wyraził zgodę na Bukę, ponieważ ją poznał - ujrzał jej twarz.

Obok zgody na siebie oraz zgody na Innych Korczak pisze również o zgodzie na świat, ponieważ jedynie akceptując świat, człowiek może zaakceptować Innych oraz siebie samego. Także ta teza ma głębokie podłoże filozoficzne, ponieważ Sartre stwierdził, że człowiek musi ponosić odpowiedzialność za siebie i za cały świat (zob. Sartre 680). Zgadzam się z Autorką, że prawdziwe poczucie szczęścia i zadowolenia z siebie może przynieść jedynie wcielenie w życie wszystkich trzech i mpe r a t y w ó w : zgody na siebie, zgody na Innych, zgody na świat.

Wątpliwości wzbudza teza Korczak, którą postawiła w zakończeniu swej książki, mianowicie, że „żyjemy w świecie, w którym normatywność się upolityczniła” (Korczak 110). Autorka nie precyzuje w żaden sposób, jak rozumie to upolitycznienie, dlatego uważam, że tezę tę należy poddać falsyfikacji, gdyż norma zawsze jest polityczna, tzn. służąca ujarzmianiu jednostek i osiąganiu przez nie określonych celów. Twierdzę, że nawet gdyby imperatyw społeczny nakazywał, aby każdy człowiek afirmował swe życie i odnosił się do każdego Innego z szacunkiem i szczerą dobrocią, to wtedy także byłby on polityczny, gdyż jego wprowadzenie miałoby na celu utworzenie społeczeństwa tolerancyjnego, w którym nie ma miejsca na przemoc i przestępczość. Norma zatem w każdym wymiarze jest polityczna, gdyż zawsze będzie służyła okiełznaniu i ujarzmieniu jednostek w społeczeństwie. Świat 
natomiast, w którym społeczne nakazy nie są dookreślane w kategoriach politycznych, jest w mojej ocenie światem utopijnym.

W książce autorka pisze także, że Muminki są szczęśliwymi egoistami (Korczak 15, 37), dzięki czemu mogą wyrażać tytułową zgodę na siebie. Uważam, że jest to trafna teza, ponieważ egoizm jest ważną cechą konstytuującą naszą tożsamość. Nie jest ona pejoratywna: egoistą jest ktoś, kto jest świadom swej egzystencji, kto ponosi odpowiedzialność za swe czyny i realizuje własne cele, by w ten sposób móc osiągnąć szczęście. Co więcej, bycie egoistą stanowi spoiwo opisywanego przez Korczak ciągu przyczynowo-skutkowego: „zgoda na siebie - zgoda na innych - zgoda na świat". Nie będąc bowiem egoistą, jednostka nie jest w stanie zaakceptować własnej podmiotowości i egzystencji, gdyż staje się altruistą poświęcającym się dla drugiego człowieka i wyrażającym jedynie zgodę na Innych bądź też samolubem odrzucającym odpowiedzialność za Innego i afirmującym samego siebie. Możemy zatem zasadnie sformułować wniosek, że jedynie egoista jest zdolny wypełnić trzy „imperatywy zgody” zaproponowane przez Korczak. Badaczka, mimo słuszności swej tezy, nie dostrzega jednak różnicy między egoizmem a samolubstwem i pojęcia te traktuje synonimicznie . Autorka raz pisze, że „nie ulega wątpliwości, że Muminki i ich przyjaciele to szczęśliwi egoiści" (Korczak 37), w innym miejscu natomiast: „W książkach tych [tj. w opowieściach o Muminkach - uzup. M.B.] dominuje beztroska, s a m ol u b n a [podkr. M.B.] - iście epikurejska - chęć zapewnienia sobie szczęścia i zadowolenia" (Korczak 39). Moim zdaniem oba te pojęcia należy rozdzielać, gdyż bycie egoistą lub samolubem prowadzi do odmiennych konsekwencji dla funkcjonowania jednostek w społeczeństwie.

Korczak, co wykazałem w tej recenzji, w niektórych miejscach nierozważnie używa terminów, takich jak inność, obcość, esencja, imperatyw socjalizacji, norma czy opresja, co sprawia, że czytelnik nie ma jasności co do zrozumienia określonych pojęć. Mimo to uważam, że książka zasługuje na uznanie, ponieważ stanowi przyczynek do dyskusji na temat socjalizacji płciowej, inności, wyobcowania oraz społecznego wykluczenia. Muminki są jedynie ilustracją, którą autorka posługuje się w celu opisywania świata i sytuacji społecznych. Korczak pisze o rzeczywistości, której sama by pragnęła, tzn. wolnej od nietolerancji, opresyjnych imperatywów socjalizacyjnych oraz od wyobcowującej i wykluczającej normy heteroseksualnej. Zgoda na siebie to książka o pragnieniu akceptacji, o poszukiwaniu wolności warunkującej swobodne działanie i dookreślanie własnej podmiotowości. Gdybyśmy chcieli sformułować wniosek płynący z tej książki, to mógłby on być następujący: „Różnorodność jest źródłem harmonii społecznej” (Korczak 60). 


\section{BIBLIOGRAFIA}

Korczak, Aleksandra Maria. Zgoda na siebie. Przełamywanie imperatywu socjalizacji w cyklu o Muminkach autorstwa Tove Jansson. Warszawa: Wydawnictwo Stowarzyszenia Bibliotekarzy Polskich, 2016.

Lévinas, Emmanuel. Inaczej niż być lub ponad istotą. Przeł. Piotr Mrówczyński. Warszawa: Fundacja Aletheia, 2000.

Lippmann, Walter. „Public opinion” 1992. Web. 01.03.2017. <http://wwnorton.com/college/history/ america-essential-learning/docs/WLippmann-Public_Opinion-1922.pdf>.

Sartre, Jean-Paul. Byt i nicość. Zarys fenomenologii ontologicznej. Przeł. Jan Kiełbasa. Kraków: Wydawnictwo Zielona Sowa, 2007. 